\title{
SZÍNES ÉS HAGYOMÁNYOS (KORRÓZIÓS) MARATÁS ÖSSZEHASONLÍTÁSA AZ ÖNTÖTTVASAKNÁL
}

\section{COMPARISON OF THE COLOUR METALLOGRAPHY AND THE ETCHING BY CAST IRON}

\author{
Huszák Csenge ${ }^{1}$, Nagyné Halász Erzsébet ${ }^{2}$ \\ Óbudai Egyetem, Bánki Donát Gépész és Biztonságtechnikai Mérnöki Kar, Anyag-és \\ Gyártástudományi Intézet, Anyagtechnológiai Intézeti Tanszék, Cím: 1081 Magya- \\ rország Budapest, Népszínház utca 8; Telefon / Fax: +36-1-666-5352 \\ Ihuszak.csenge@bgk.uni-obuda.hu \\ nagyne.halasz@bgk.uni-obuda.hu
}

\begin{abstract}
The etching is the final preparation step in metallography, in order to reveal the microstructure, grain boundaries and phases. Two etching processes are described in this article: the conventional etching and the colour metallography. While the former is applied more often, due to the simplicity of the process, the latter provides more detailed image of the microstructure of the analysed metals and alloys. For this reason, colour metallography is becoming more popular. For both etching techniques, chemical composition of the etched material has to be considered for the identification of the microstructure, a special etchant mix is needed for particular alloys.
\end{abstract}

Keywords: metallography, etching, microscope

\section{Összefoglalás}

A maratást a metallográfia befejező müveleteként alkalmazzák, hogy a szövetszerkezeten kívül a fázisok is láthatóvá váljanak. Két típusára fogunk most kitérni: a hagyományos, azaz a korróziós és a színes maratásra. Míg az előbbit elterjedtebben alkalmazzák, hiszen az alkalmazása is egyszerübb, viszont az utóbbi segítségével részletesebb képet kapunk a vizsgált fémek és ötvöztek mikroszerkezetéről. Éppen emiatt kezd egyre nagyobb körben elterjedté válni a színes maratás. Mindkét maratási típusnál figyelembe kell venni a maratandó anyag összetételét, mert egyes ötvözeteknél speciális maratószer kikeverésével lehet csak a szövetszerkezetet jól felismerhetővé tenni.

Kulcsszavak: metallográfia, maratás, mikroszkóp

\section{Bevezetés}

A csiszolatok elkészítése sok tudományágban elterjedt, hiszen ez által lehet megállapítani a vizsgált anyag szerkezetét. A biológiában - elsősorban az orvostudományban-, a kőzettanban és a fémtani vizsgálatok során alkalmazzák. A fémek és fémötvözetek ilyen jellegü vizsgálatát me- tallográfiának nevezik, ami a fémek síkcsiszolatainak készítésével és elemzésével foglalkozik. A főbb lépései a következők:

- mintavétel (vizsgált anyag egészére jellemző, fontos a hütés)

- mintabefogás és beágyazás (amennyiben a próbatest apró vagy kedvezőtlen alakú);

- csiszolás (több lépésben, egyre fiomabb szemcséjü csiszolópapírokon); 
- polírozás (polírozó szerrel nedvesített polírozó korongon, 2-3 lépésben);

- maratás (az ötvözettől függő maratószerrel);

- mikroszkópos vizsgálat.

(Mintadarabtól és a vizsgálat céljától függően a mintabefogás és a beágyazás, illetve a maratás akár el is hagyható.)

A mai metallográfiának és a mikroszkópos vizsgálatoknak az alapjait Henry Clifton Sorby munkásságának köszönhetjük. Ő alapította meg a fémmikroszkópiát, azaz a metallográfiát, ami manapság elengedhetetlen része a kohászatnak, így a mindennapjainkhoz is elengedhetetlen lett, természetesen csak közvetetten.

\section{A maratás}

A fémtanban elengedhetetlen manapság a metallográfia használata, így ezt is továbbfejlesztették. A helyszíni metallográfiánál a replika technika segítségével képesek megállapítani a szövetszerkezeti állapotot. Így roncsolásmentesen tudják megvizsgálni a nem mozdítható berendezéseket. Különböző szoftvereket fejlesztettek ki a szövetszerkezetek felismerésére, illetve az összetétel meghatározására.

$\mathrm{Az}$ elmúlt évszázadban egyre több maratószert kísérleteztek ki, ezeknek a célja a szövetszerkezet láthatósága, könnyebb elkülöníthetősége volt. Hiszen a maratás a szövetszerkezetnek a részleteit teszi láthatóvá: a szemcsehatárokat és az egyes fázisokat. Heterogén szövetszerkezet esetén az elektropozitívebb fázis krisztallitjai maródnak erősebben, miközben a másik fázis egyáltalán nem vagy kevésbé maródik. Homogén szövetszerkezetnél a krisztallitok oldási potenciálja azonos, viszont a krisztallitok határai gyorsabban oldódnak, emiatt válnak láthatóvá a szemcsehatárok.

A következő két ábrán egy maratlan, illetve egy maratás utáni képet láthatuk gömbgrafitos öntöttvasakról. (1. és 2. ábra)

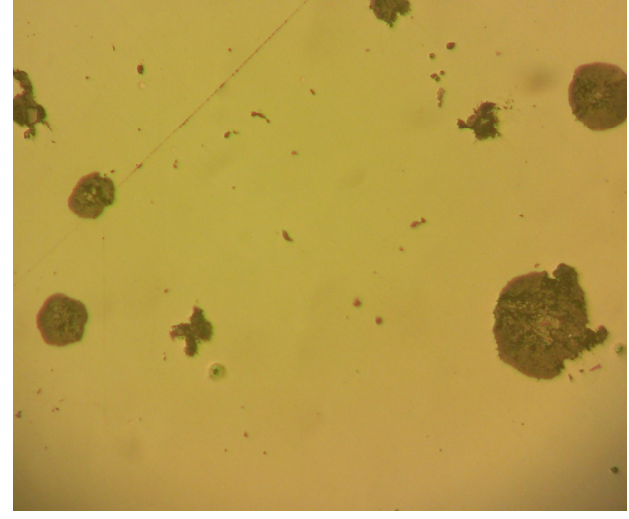

1. ábra. Maratlan öntöttvas

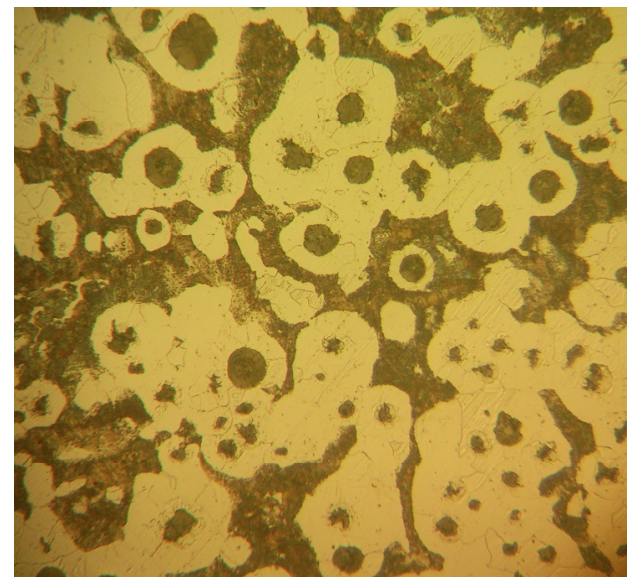

2. ábra. Maratott öntöttvas

A vasötvözetek körében leggyakrabban használt maratószer a Nital (salétromsavnak a 2-10\%-os alkoholos oldata), de speciális recepteket is fejlesztettek ki.

Többféle maratási módszer létezik, ezek közül most a hagyományosra, azaz a korróziósra, illetve a színes maratásra fogunk kitérni.

\subsection{A hagyományos (korróziós) és a színes maratás összehasonlítása}

A hagyományosnak nevezhető maratás után is kapunk információt a szemcsehatárokról, illetve a fázisokról, viszont ezeket sok esetben csak nehezebben 
lehet megkülönböztetni, mivel legtöbbször egy korlátozott színskálán mozognak. Ennek a problémának a kiküszöbélésre használják a színes maratást. A színes maratásnál a minta felületén $0,04-0,5 \mu \mathrm{m}$ vastagságú filmréteget hoznak létre, így tudják a megfelelö elszíneződést elérni. Ezek a vékony filmrétegek oxid, szulfid, komplex molibdát, szelén vagy kromát típusú filmek lehetnek. Ezek az interferencia hatás miatt különbözőképpen színeződnek el, ezáltal a fázisok is színben eltérőek lesznek, így megkönnyítve az azonosításukat.

\section{2. Öntöttvasak maratása}

Az MSZ EN ISO 945:2000-es szabvány hat alapvető grafittípust határoz meg (3. ábra):

-I: lemezes eutektikus grafit

- II: csillag vagy pókszerủ képződménnyé összeállt grafit

- III: vaskos, tompa végủ átmeneti grafit

-IV: apró, szabálytalan, a temper öntvényekben található tempergrafit

-V: nem tökéletesen szabályos gömbgrafit

- VI: tökéletesen gömb alakú grafit

Ezeknek az alakját már polírozás után is könnyen beazonosíthatjuk.

A maratás után természetesen már nem csak az öntöttvas alaktípusát állapíthatjuk meg, hanem a szemcsehatárokat és a fázisokat is. Speciális maratószereket kísérleteztek ki az öntöttvasak különböző típusaira is, bár a bevettnek mondható Nital is alkalmas az öntöttvasak maratására, de ezzel csak a hagyományos maratás vitelezhető ki. Ezen kívül a Pikrált és a Klemm és a Beraha reagenseket ajánlják és az utóbbiakat alkalmazzák a színes maratási eljárásoknál.

A 4. és 5. ábrán láthatjuk a különbséget a hagyományos és a színes maratás között. Mindkét képen jól kivehető az öntöttvas alaktípusa, viszont a további fázisokat csak a színesen maratott mintánál tudjuk megkülönböztetni.
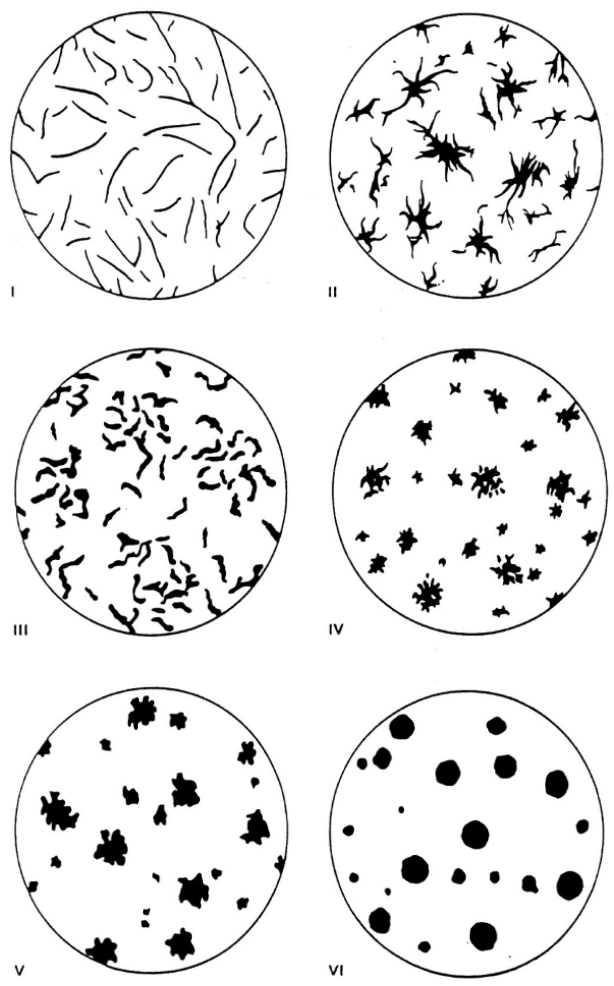

3. ábra. Grafit alaktípusok I-VI

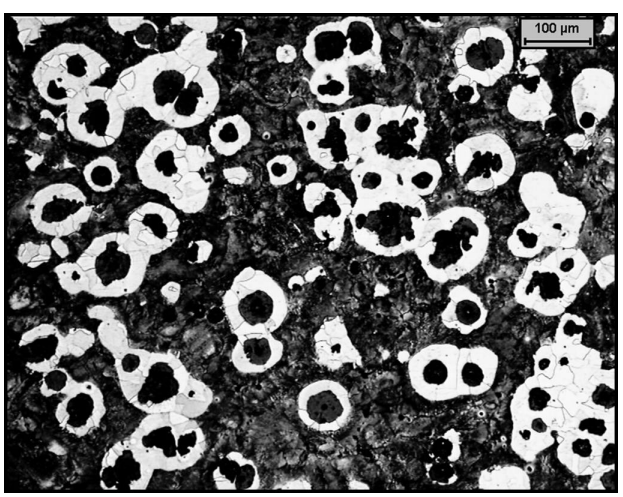

4. ábra. Gömbgrafitos öntöttvas szövetképe hagyományos maratás esetén 


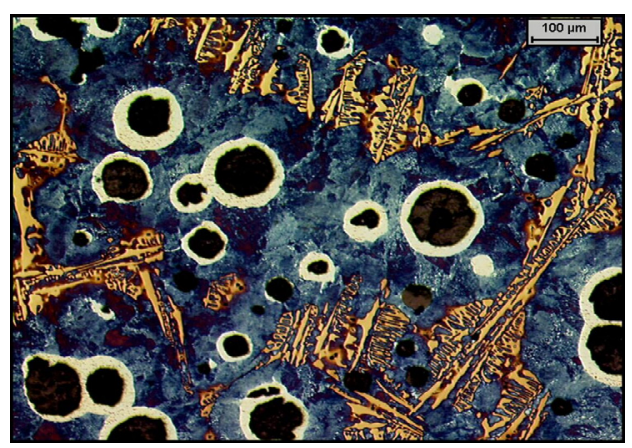

5. ábra. Gömbgrafitos öntöttvas szövetképe szines maratás esetén

\section{Következtetések}

$\mathrm{Az}$ általunk bemutatott metallográfiai eljárások mind a kutatás, mind az ipar számára elengedhetetlen vizsgálati módszerek. A színes maratás lehetőséget nyújt, hogy a szövetszerkezet vizsgálata még teljesebbé váljon.

A marószerek folyamatosan fejlődnek, hiszen a kohászat és az acélgyártás is egyre újabb mikroszerkezetet mutató anyagokat gyárt az ipar kihívásainak megfelelően. A metallográfiai vizsgálatok emellett eszközei lehetnek a káresemények okainak felderítésében és a gyártástechnológia fejlesztésében.

\section{Szakirodalmi hivatkozások}

[1] ASM Handbook Volume 9: Metallography and Microstructures. ASM International, 2004, 493-512; 565-587.

[2] George F. Vander Voort: Color Metallography. Microscopy Today, 2005 november, 22-27.

[3] Tóth László, Dávid Eszter, Erdei Timotei István: A metallográfia története, Henry Clifton Sorby. Anyagvizsgálók lapja, 2013 11-2, 52-55.

[4] Magyar Szabvány Testület, MSZ EN ISO 945:2000 Öntöttvas

[5] Kardos Ibolya: Digitális képfeldolgozás és szines metallográfia alkalmazása gömbgrafitos öntöttvasak szövetszerkezetének jellemzésére. Kerpely Antal Anyagtudományok és Technológiák Doktori Iskola, Miskolc, 2009.

[6] http://www.grimas.hu/metallografia/labortec hnika-es-maratas/maratoszerek-eslaboreszkozok/maratoszerek/ (2017.01.18.) 